\title{
Plunder and resistance in traditionally occupied territories of the Tapajós and Trombetas basins, Pará state, Brazilian Amazonia
}

\author{
Bruna Cigaran da Rocha \\ Diego Amoedo Martínez \\ Hugo Gravina Affonso \\ Susan Aragon \\ Vinicius Honorato de Oliveira \\ Ricardo Scoles
}

${ }^{I}$ Historical and Political Ecology of the Trombetas, Tapajós and Xingu River basins Research Network; Anthropology and Archaeology Program, Federal University of West Pará state, Santarém-Brazil.

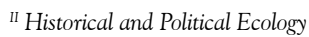
of the Trombetas, Tapajós and Xingu River basins Research Network; Anthropology and Archaeology Program, Federal University of West Pará state, Santarém-Brazil.

${ }^{I I I}$ Historical and Political Ecology of the Trombetas, Tapajós and Xingu River basins Research Network; Post-graduate Program in Amazonian Agricultures, Amazonian Institute of Family Agriculture, Federal University of Pará, Belém-Brazil.

${ }^{\text {IV }}$ Historical and Political Ecology of the Trombetas, Tapajós and Xingu River basins Research Network; Post-graduate Program in Amazonian Natural Resources, PPGRNA, and State, Santarém-Brazil; INTE-PUCP, Lima, Peru.

\begin{abstract}
In understanding contemporary Latin America, a critical post-developmental approach is particularly relevant. This approach closely links modernity to coloniality and its debates are permeated by the concept of colonized nature and by trenchant critiques of 21 st century neo-extractivism. This article presents the social diversity and biocultural legacies of forest peoples who live in the basins of the Tapajós and Trombetas rivers. We present an analysis of particular areas and locales, to reveal ways that plunder is perpetrated by capital, in collusion with different spheres of the State. This analysis, in turn, allows us to reflect on different forms of forest peoples' resistance in defence of their traditionally occupied territories and ways of life.
\end{abstract}

Keywords: Tapajós, Trombetas, Political Ecology, Plunder, Resistance

São Paulo. Vol. 24, 2021

Featured Topic:

Decolonial Insurgences and Emancipatory Horizons: Contributions of Political Ecology

DOI: http://dx.doi.org/10.1590/1809-4422asoc20200095r1vu2021L3AO 
${ }^{\mathrm{V}}$ Historical and Political Ecology of the Trombetas, Tapajós and Xingu River basins Research Network; Anthropology and Archaeology Program, Federal University of West Pará state, Santarém-Brazil.

${ }^{\mathrm{V}}$ Historical and Political Ecology of the Trombetas, Tapajós and Xingu River basins Research Network; Post-graduate Program in Amazonian Natural Resources, PPGRNA, and Centre of In terdisciplinary Training, Federal University of West Pará state, Santarém-Brazil.

\section{Introduction}

In understanding contemporary Latin America, a critical post-developmental approach is particularly relevant. This approach closely links modernity to coloniality and its debates are permeated by the concept of colonized nature and by trenchant critiques of 21st century neo-extractivism (SVAMPA, 2019). The article presents the social diversity and biocultural legacies of forest peoples who live in the basins of the Tapajós and Trombetas rivers. We present an analysis of particular areas and locales, to reveal ways that plunder is perpetrated by capital, in collusion with different spheres of the State. This analysis, in turn, allows us to reflect on different forms of forest peoples' resistance in defense of their traditionally occupied territories and ways of life.

Historical ecology points to the importance of understanding long term historical processes of construction of landscapes, conceiving of the relations between "culture" and "nature" as dialogic and dialectical rather than dichotomous (BALÉE, 1998). Political ecology, in turn, leads us to reflect on how power relations affect the management of the environment (ALIMONDA, 2011). An autochthonous form of political ecology has developed in Latin America (ALIMONDA, 2017), which is of international relevance and exists in a foundational and permanent state of construction of theoretical and practical multidisciplinary knowledge (LEFF, 2003). For Joan Martínez- Alier (2015), the object of study of political ecology are the distributional ecological conflicts; conversely Latin American authors such as Enrique Leff and Arturo Escobar put more focus on aspects related to place, culture and political epistemology (LEFF, 2003; ESCOBAR, 2005). For Eduardo Gudynas (2014), in turn, the great challenge of this interdisciplinary science is to simultaneously ecologize politics and politicize ecology.

The authors of this article are part of the Historical and Political Ecology of the Trombetas, Tapajos and Xingu basins Research Network based at the Federal University of Western Pará, in Santarém. We believe that the understanding of current biotic conditions requires a recognition that landscapes have been both altered by human societies in the past and are actively maintained by the forest peoples in the present (e.g. SCOLES; GRIBEL 2011; BALÉE et al., 2020). Our work focuses on of conflicts involving indigenous peoples and traditional communities in the region, and in supporting their struggles in asymmetric disputes with big capital and the State.

Forms of resistance to plunder and consequent territorial 
expropriation in the Tapajós and Trombetas basins are exercised in multiple ways and involve different actors. They are, on the one hand, a continuous, latent and persistent process, therefore 'everyday' (SCOTT, 2002); on the other hand, resistance is also made up of direct actions that paralyze commodity ventures or flows, achieving great visibility. Other forms involve the mobilization of government agencies that are sensitive to causes and involved in the formulation and alteration of public policies. The mere existence and persistence implied in the presence of indigenous peoples and traditional communities in the current scenario constitutes a sign of their capacity for reinvention. As Das and Poole (2008) argue, social groups that inhabit the margins of the State are actors that challenge structures that appear to be monolithic. Here we analytically centre the margin, its inhabitants and their forms of resistance, paying particular attention to the positions of the State in these contexts.

\section{Methodological procedures}

The present work is marked by the collaboration of different fields of knowledge, such as archaeology, anthropology, geography and ecology. It was developed in meetings, discussions and joint research carried out in the Trombetas, Tapajós and Xingu basins, in which environmental inequalities and the struggles that indigenous peoples and traditional communities have for territorial and social rights are analysed, from theoretical and social perspectives and methodological tools mentioned in the introduction. This article gives also an overview of some of the dispossession processes and resistance that we have followed over more than a decade of operation.

\section{The Trombetas and Tapajós basins, their social diversity and biocultural heritage}

The watersheds of the Tapajós and Trombetas rivers are part of the Amazonian craton, a shield of the American continent located to the south and north of the Amazonian sedimentary basin (HOORN; WESSELINGH, 2010; Figure 1). Both rivers pass through geological formations that are billions of years old and with low fluvial erosion, they are poor in sediments. However, the high density of phytoplankton present in Tapajós lends a greenish tone to its colour (MORAIS, 2008), when whereas, by going through numerous streams and flooded forests (igapós) that contain abundant organic matter, the waters of the Trombetas River are acidic and tinted with dark tones (HORBE; OLIVEIRA, 2008). Both basins act as bridges, connecting the Central Brazilian Plateau to the Amazon valley to the south and the Guiana Shield to the north. 
Figure 1. Location of the Tapajós and Trombetas sub-basins. Map by Vinicius Honorato

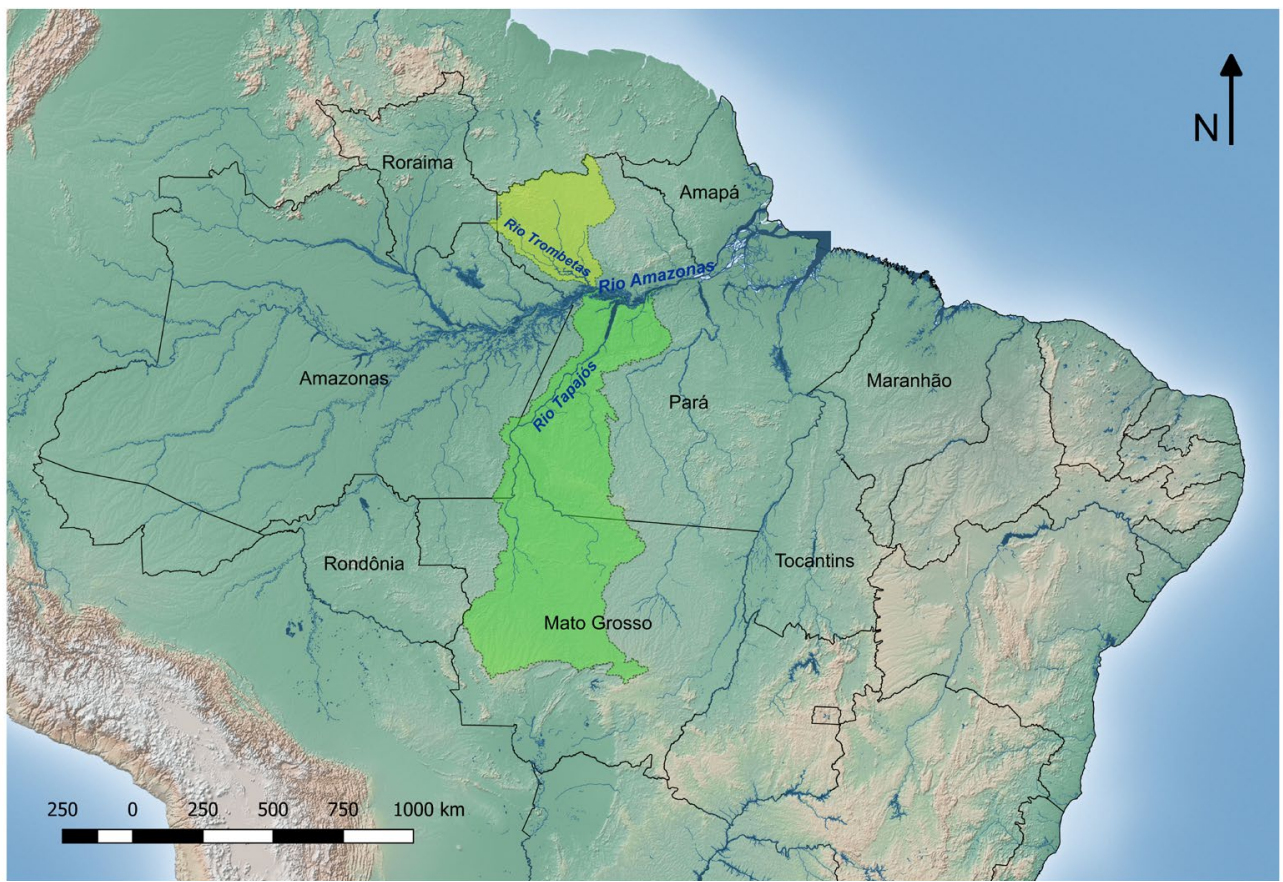

Sources: IBGE; Natural Earth online.

The Tapajós and Trombetas basins are very rich in terms of biodiversity. By connecting the cerrado to the Amazon rainforest, the Tapajós basin has less humid climatic conditions in the south, where the dominant phytophysiognomy is very heterogeneous, composed mainly of savanna fields and open rainforest. Further downstream, the dominant vegetation is dense rainforest (SCOLES, 2016). The Trombetas basin, meanwhile, belongs to the endemic region of the Guianas (SILVA et al., 2005), with vegetation dominated by dense upland dense rainforest, flooded forests (igapós) and patches of white sand meadows (IBAMA, 2004), therefore having heterogeneous ecosystems and geomorphologies. Both rivers have, in their high courses, stretches of water that are difficult to navigate, and freer stretches, which represent the meeting of the Guyanese and Brazilian shields with the Amazon valley, respectively.

In the Amazon, there is evidence of human occupation and transformation of the various ecosystems that make up the basin - for at least twelve thousand years (SHOCK; MORAES, 2019). Despite the demographic collapse that followed the European invasion of the region - leading to an estimated depopulation of around 90\% (KOCH et al., 2019) - it can be said that since its settlement by the ancestors of current indigenous peoples, the Amazon has never been empty. This is because the arrival of Africans and their enslaved descendants (ACEVEDO; CASTRO, 1998; FUNES, 2015), as well as Brazilian northeasterners, from the 19th century (ALMEIDA, 1993), led to the occupation and constitution of new territories, and a sociality shaped by important exchanges of 
knowledge and practices with indigenous peoples, with whom these migrants interacted in various ways, including conflict, marriage, trade and solidarity.

The Trombetas River is known for the diversity of peoples speaking Karib languages and isolated peoples. There are also speakers of Arawak and Tupi (Zo'e) languages. Ancient Arawak occupations are evidenced by the presence of ceramics belonging to the Pocó Tradition (NEVES et al., 2014), dated between 200 BC and 400 AD in this region (GUAPINDAIA, 2008), and to the initial formation of anthropogenic soils known as Terra Preta de Indio (NEVES, 2006). In the Tapajós basin, indigenous peoples belonging the Tupi, Karib, Arawak and Jê linguistic stocks are mentioned in records written between the 16th and 20th centuries. In the Tapajós River, Tupian peoples, such as the Munduruku, predominated historically, especially above rapids and interfluvial areas (ROCHA, 2017). There is indirect evidence that points to human occupation of this river since the end of the Pleistocene or the beginning of the Holocene (SIMÕES, 1976; ROCHA, 2017; ).

The European colonization of the Amazon led to profound transformations, which can be understood as a series of shocks that would lead to a wide social reconfiguration of the region. Amerindian reactions to processes of conquest and colonization varied dramatically, which led to very divergent outcomes for the various peoples involved, from decimation to the formation of "new societies and new types of society" (MONTEIRO, 2001, p.55, emphasis in the original). Taking the Munduruku people as an example, Whitehead (1993) argued that some Amerindians - through flexibility and innovation - managed to ensure that European conquest was either delayed or did not happen in certain locations. We can observe how, throughout the Portuguese colonization process this Amerindian people employed a wide range of responses to ensure their survival, ranging from armed resistance to collaboration with the Portuguese after a truce agreed at the end of the eighteenth century (ROCHA, 2017).

Two hundred years ago, enslaved Africans and their descendants were brought to the lower Amazon - which includes Santarém, Monte Alegre, Óbidos and Alenquer -, to work on cattle farms and cocoa, coffee, rice and cane plantations. Some of them escaped, and the Trombetas region provided an appealing landscape for this. Its intricate system of lakes, boreholes and rapids provided protection against capture expeditions and enabled the establishment of mocambeira or quilombo communities (ACEVEDO; CASTRO, 1998; FUNES, 2015). Descendants' reports include descriptions of how, before fleeing, women collected different types of seeds and hid them in their hair, to ensure the sustenance of the communities that were subsequently formed (FUNES, 2015).

From the second half of the 19th century, fleeing drought and attracted by promises of work in the rubber economy, northeastern migrants arrived in the Tapajós and Trombetas rivers to work as rubber tappers. Mostly men, they would form new social groups on the upper Tapajós, through marriages - usually forced - with indigenous women (TORRES, 2008), whose presence "is a vital element for understanding their forms of occupation and reproduction in that space" (TORRES, 2016), bequeathing to these rubber tappers a millenary framework of knowledge about the forest.

Coeval processes took place on the Trombetas River, where northeastern migrants 
arrived to work in plant extraction activities, whose products would also be traded with the region's regatões (river trading watercraft). The fall in rubber prices in 1913 would lead to the rubber tappers' abandonment of rubber plantations in the upper Tapajós, which led to the emergence of a forest peasantry (ALMEIDA, 1993; TORRES, 2008). Although the rubber industry had never reached the same magnitude on the Trombetas River, when compared to the Tapajós, the drop in rubber prices had similar repercussions, being fundamental in the process of formation of the riverside society in that area. In the 1940s, new migrants, "rubber soldiers", would come from the Northeast to again extract latex from rubber trees after the Japanese takeover of British rubber plantations in the Malay Peninsula during World War II.

Over millennia, and in the present day, these different indigenous peoples and traditional communities have cumulatively promoted landscape changes (BALÉE, 1989; CARNEY; VOEKS, 2003), based on a series of management practices (LEVIS et al., 2017). These peoples imbued these landscapes of meaning, giving them names - and toponymic landmarks often act as mnemonic activators of historical or mythical events. Such is the case of the rapids of the Tapajós (POVO MUNDURUKU, 2013) and Trombetas (FUNES, 2015) rivers, which, after the European invasion, became barriers to colonization, slowing or delaying their progress and acting as areas of refuge, both for indigenous peoples (HARRIS, 2018; ROCHA, 2017) and for the newly constituted quilombola communities - in the case of the Trombetas river, even during the Cabanagem period (ACEVEDO; CASTRO, 1998). The territoriality of these diverse groups involves locales of hunting, gathering, fishing, extractivism and swiddens, such as the so-called "work points" of the ribeirinhos of the lower Trombetas (AFFONSO, 2018).

Despite the ancient and extensive presence of indigenous peoples and traditional communities in Brazil, there has been a notorious lack of recognition of their territorial and social rights. From the 20th century onwards, human presence in the Amazon was repeatedly denied and the region was portrayed as a demographic void, with emphasis on its "natural" characteristics. In the 1930s, with the ambition of Getúlio Vargas to "integrate" the Amazon with the rest of the country (ARBEX JR., 2005), the "vocation" of the region was defined as to "navigation and transportation, agricultural colonies and rubber production" (BUENO, 2002, p.73). The discourse of the demographic void continues to be reproduced and when human presence is recognized, it is presented as an obstacle to progress (ALARCON; GUERRERO; FURUIE, 2016).

\section{The struggle for land on the Tapajós river}

According to Martins (1996, p. 26), "the history of recent frontier expansion is a history of destruction. But it is also a story of resistance, revolt, protest, dream and hope". Since the 1960s, the Tapajós basin has been the scene of a series of attacks by big capital, with strong support from the State, justified by the "development" paradigm (ALARCON; GUERRERO; TORRES, 2016) (Figure 2). Such offensives feature different "fronts" that are connected. One of them is the advance of the "agricultural frontier", coming from Mato Grosso, an expansion that results from processes of land grabbing and speculation 
of public lands (TORRES, 2005; TORRES et al., 2017). Access to public lands for large corporations has been greatly facilitated, especially along federal highways (OLIVEIRA, 2005).

Figure 2. Map of the Tapajós basin with the location of protected areas, industrial and infrastructure projects and threats mentioned in the text

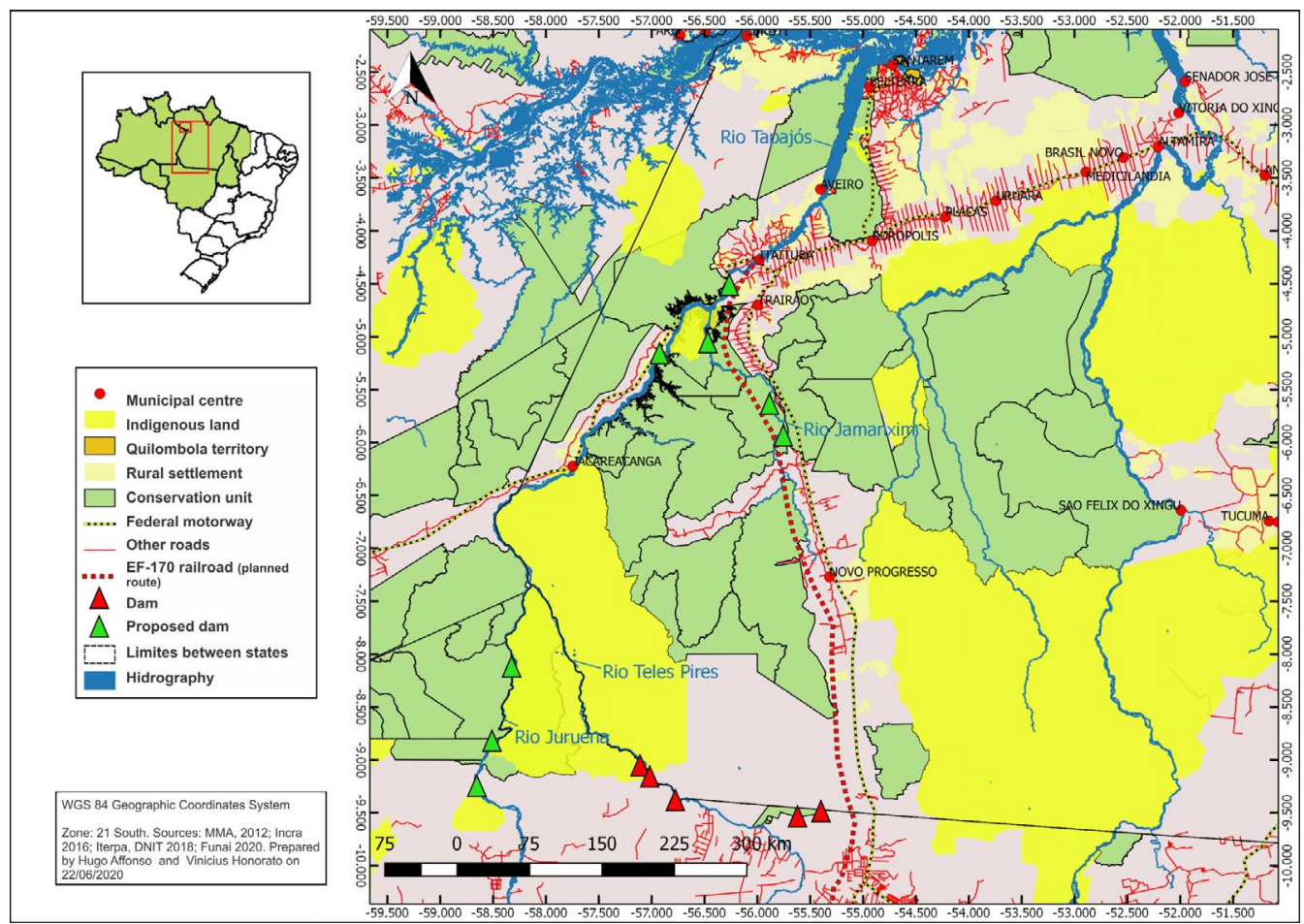

Source: Elaborated by the authors, 2021.

Public land outside of protected areas is vulnerable to private appropriation and alienation by land grabbing, which, in turn, is closely related to processes of deforestation and violence (TORRES, 2012; 2018; TORRES; DOBLAS; ALARCON, 2017). In the Tapajós basin, as well as throughout the Amazon, the State has acted to facilitate the privatisation of public non-reserve land over the past 15 years and, under the Bolsonaro government, it has acted to facilitate the theft even of public lands in protected areas (TORRES; CUNHA; GUERRERO, 2020).

Another "front" that advances on the Tapajós is related to the advance of the mining frontier. Consultations with the National Department of Mineral Research (DNPM) show that "the Tapajós basin is covered with processes for authorization of mineral prospecting and concession for mining of different ores" (ALARCON; GUERRERO; TORRES, 2016). Such requests apply even to conservation units (UCs) and indigenous lands (TIs), in the expectation of legislative changes that authorize this type of exploitation, such as Bill 1.610 / 1996. The planned construction of hydroelectric dams, in turn, is related to 
the supply of energy for these works.

The establishment of infrastructure and logistics for the transportation of commodities, driven from the 2000s through a joint venture between the paving of BR-163, the installation of Teles Pires-Juruena-Tapajós waterway and the construction of grain ports in Miritituba and Santarém has increased land speculation and the expansion of soy and maize plantations in its vicinity, as is the case with Planalto Santareno and the district of Miritituba. Understanding the supposed vocation of the Tapajós basin to act as a bridge to provide an "outlet from the north" for grains produced in the cerrado (ALARCON; GUERRERO; TORRES, 2016), the project provided planned to construct locks to allow the navigation of industrial barges along the dams projected for the Tapajós Complex - which foresaw for the construction of 43 large hydroelectric dams in the basin (FEARNSIDE, 2015). The presumed "sustainability" of waterways and dams, used as an argument in favour of the project, ignored the fact that the waterway would serve the "expansion of predatory economic activities, which are known to have advanced over the territories and ways of life of indigenous, riverside inhabitants, peasants and other groups" (FEARNSIDE, 2015, p.56-57), leading to accumulation by dispossession (HARVEY, 2004).

Connected to this proposal are the plans for the construction of the EF-170 railway, which is about one thousand kilometres long, running in parallel to the BR-163 highway and connecting the municipalities of Sinop (Mato Grosso) and Itaituba (Pará). Known as "Ferrogrão ", the project has been celebrated as a "second agribusiness revolution" (ANGELO, 2019), and expects to transport up to 20 million tons of grain through the ports on the Tapajós and Amazon River. In a conservative estimate, it is estimated that the project would boost the demand for land and raise deforestation by at least $2040 \mathrm{~km} 2$ (ARAÚJO et al., 2020). This is because the expectation generated by the implementation of these undertakings leads to "speculative deforestation" (ALARCON; GUERRERO; TORRES, 2016, p.43) related to land grabbing.

The Munduruku people, owing to the threat posed by the Tapajós River dam and its tributaries in terms of the destruction of their territory - which goes far beyond the limits of officially recognised indigenous lands or those in the process of recognition by the State (POVO MUNDURUKU, 2013), established a unique resistance process with the foundation, in 2010, of the Ipereğ Ayũ Movement (LOURES, 2017). Strategies were outlined through dialogue with a constellation of allies, partners and supporters, such as the Federal Prosecution Service (MPF), NGOs, researchers, rural workers' unions, representatives of the Catholic Church, other social movements, in addition to other indigenous peoples and traditional communities. In this way, the Munduruku started to demand the guarantee of their territorial rights in a broader way, demanding the demarcation of their lands (especially TI Sawre Muybu and, more recently, TI Sawre Bap' in), as well as their right to free consultation, prior and informed consent (FPIC), as provided for in Convention 169 of the International Labour Organization (ILO). Internal cohesion has been guaranteed by a decision-making process linked to the holding of assemblies in different villages, over the course of days, with extensive discussions in the Munduruku language. 
The Munduruku resistance process involved direct actions that were very effective in opening up the ongoing clash of worlds (KRENAK, 2019). An example was the arrest and expulsion of researchers who worked on the environmental licensing of the Jatobá dam (part of the Tapajós Complex), in 2013, and the confiscation of fauna specimens from collection, understood by the Munduruku as a violation of nature. Another, more recent example, was the occupation of the Alta Floresta (MT) Natural History Museum in 2019, when funerary urns excavated during the licensing process for the Teles Pires hydroelectric plant were buried again (LOURES; BRANFORD, 2020), an unprecedented action in Brazil. In addition, a recurring practice of this indigenous people involves the dissemination of their actions through letters prepared collectively, and often translated into Portuguese, English and Spanish, on websites created for this purpose ${ }^{1}$. The letters expose their political ontology (ESCOBAR, 2005) and clearly show the clash of worlds (KRENAK, 2019), a conflict between cosmologies, which affirm Munduruku resistance as an autonomous action, responding to a call that is not perceptible or comprehensible to anyone who understands rivers, lakes, lands only as a source of resources.

It should be noted that actions carried out by the Munduruku, such as the occupation of the Belo Monte hydroelectric construction site in 2013, with representatives of other indigenous peoples and of the traditional Montanha and Mangabal community, and the interruption of BR-230 (Transamazônica Highway) traffic, in 2017, had the support, in the first action, of the dam workers (LOURES, 2017) and, in the second, truck drivers (TORRES; BRANFORD, 2017). The formation of alliances between the Munduruku and other forest peoples, such as the beiradeiros of Montanha and Mangabal (LOURES, 2017; TORRES, 2015) was, in fact, essential for the realization of the autodemarcation of the territories of Dace Kapap Eïpi (officially known as TI Sawre Muybu), and the Montanha and Mangabal Agroextractive Project.

Together with the MPF and other supporters, the creation of consultation protocols has also been an extremely important instrument in demanding that the State comply with its obligations. Oliveira (2020, p.3) defines prior consultation as "a political, legal and institutional space", in which indigenous peoples and traditional communities have the "opportunity to participate in the decision-making process related to measures that affect their collective rights". Incorporated into Brazilian laws with supralegal normative status, FPIC "seeks to inaugurate a new, more symmetrical and respectful relationship between minorities and national states" (OLIVEIRA, 2020).

The actions were instrumental in delaying the environmental licensing of São Luiz do Tapajós, the largest dam planned for the Tapajós Complex. With the publication of the identification and delimitation report (RCID) of the Indigenous Land Sawre Muybu shortly after the Brazilian parliament voted to remove Dilma Rousseff, in April 2016, Ibama filed the licensing process (TORRES, 2017). Torres (2017, p.436) points to other factors that prevented the construction of dams on the Tapajós: the economic crisis deepened, together with the "profile of the Brazilian entrepreneur who never spends their own money, knowing that it is better done with public money"; the political liability of the Belo Monte

1- See https://movimentoiperegayu.wordpress.com e https://ocupacaobelomonte.wordpress.com. 
plant; the obligation imposed by the Federal Court on the government to comply with the law and carry out FPIC, and the enormous political crisis triggered by the revelation of corruption schemes that involved large contractors and public mega-enterprises.

Repeating the violations committed by the Tapajós and Teles Pires rivers dam projects (LOURES, 2017; ROCHA, 2020), the Ferrogrão project, although expected to be auctioned soon, has not even completed its environmental licensing or even started the FPIC. Moreover, the government is accused of defrauding the consultation process by attempting to co-opt local leaders (BRASIL, 2020). We are, therefore, facing a new cycle of struggles, at a moment with the most openly anti-indigenous government since the re-democratisation, which openly encourages invasions of public lands and protected areas, which has made vulnerable the protection of indigenous lands in the process of demarcation and which promotes the dismantling of state monitoring and inspection apparatus, in addition to using state agencies such as the Fundação Nacional do Índio (Funai) to erode indigenous rights.

\section{Trombetas and the dispute over the rights to use nature}

The Trombetas River basin is home to a large mosaic of protected areas (ISA, 2020; CPI-SP, 2021). Even though this means much land is protected from the market, Capital has found ways to plunder indigenous peoples and traditional communities in this region through the exploitation of the subsoil or the vegetation cover (NEPOMUCENO, 2017; AFFONSO, 2018).

In the Trombetas River basin, the creation of conservation units (UC) was related to guaranteeing social and land control in the region (WANDERLEY, 2005; COELHO; CUNHA; WANDERLEY, 2017). The 1960s marked the beginning of bauxite mining in the region, with the establishment of a macro-enterprise in the municipalities of Oriximiná, Terra Santa and Faro. As with the Tapajós, the first UC in the region - the Rio Trombetas Biological Reserve (Rebio) - was created during the military regime, in 1979, when Mineração Rio do Norte (MRN) began operations. The Saracá-Taquera National Forest (Flonast) would be created ten years later, in 1989. Rebio is a form of comprehensive protection UC that prohibits human habitation, while Flonast falls under the category of "sustainable use", whereby the presence of traditional communities is allowed according to certain rules. Both UCs overlapped territories traditionally occupied by quilombola and riverside communities.

To protect the bauxite exploitation area and its surroundings, and to ensure distance from quilombola communities, the Brazilian Institute for Forestry Development (IBDF) - the federal institution responsible for public forests between 1967 and 1989 - acted in a repressive manner against quilombolas for two decades (WANDERLEY, 2005); even today, elders recall violent and racist actions by this body (ACEVEDO; CASTRO, 1998; FUNES, 2015). MRN tries to exercise a strict control over the life and conduct of the communities that live in the surroundings of Rebio and Flonast, which can be thought 
of as an exercise in governmentality (FOUCAULT, 2008). Nepomuceno et al. (2019) use this analytical lens to characterize the counter-conducts of riberinho communities in the Flonast. If we shift the analytical focus to the quilombola territories of Alto Trombetas, we can clearly see how MRN exercises sovereignty in collusion with the State. By employing quilombolas, subsidizing community associations, building and equipping schools and the hospital in the village of Porto Trombetas, MRN created a social system that seeks to control and regulate the lives of quilombola communities directly and indirectly.

The promulgation of the 1988 Constitution and the strengthening of the quilombola movement on the Trombetas River generated important advances in the conquest of territorial rights, especially through land titling - currently there are 860,989.09 hectares, corresponding to $6.7 \%$ of the basin ${ }^{2}$ - and the recognition of usage rights in protected areas, especially the collection of Brazil-nuts in Rebio Rio Trombetas, based on an agreement between the Chico Mendes Institute for Conservation of Biodiversity (ICMBio) and three quilombola associations. In partnership with the environmental agency, quilombola communities have contributed to monitoring Brazil nut trees and planting Brazil nut trees (SCOLES; GRIBEL, 2012; 2021). Furthermore, quilombolas (both volunteers and hired by ICMBio) are, through their traditional knowledge of the management and conservation of the turtles' communities, the main agent responsible for the management of these populations, which paradoxically suffered significant reductions in the first ten years after the creation of Rebio and concurrent mining activities.

The Public Forest Management Law of 2006 established the Brazilian Forest Service (SFB) and created the possibility of concession for timber activities in areas of public forests to promote the "rational" exploitation of forest resources (BRASIL, 2006; NOGUEIRA et al., 2011) in sustainable use UCs (BRASIL, 2000), often without the consent of forest peoples whose territories are impacted (GUERRERO et al . 2020; IORIS, 2008; NEPOMUCENO, 2017). The proliferation of mineral and forestry concessions in protected areas has also represented an attack on the conservationist principles that justified the creation of UCs. Considered by the government as "sustainable" extractive activities, in the case of wood, and "public utility", in the case of mining, these projects have coated highly destructive activities in traditionally occupied territories overlapped by national forests with an ecological veneer (so-called greenwashing) and have constantly occurred to the detriment of the communities and ecosystems involved (NEPOMUCENO, 2017; AFFONSO, 2018).

The 2001 Flonast Management Plan ignored the historical presence and territorial uses of riberinho communities, such as Acari (right bank of the river), Boa Nova and Saracá (in the interior of Lago Sapucuá) (Figure 3), as well as their right to FPIC, in addition to allocating approximately two thirds of the UC to mineral and forestry concessions. In these riberinho communities, in addition to the prohibition of "work points" used for planting, hunting, fishing and collecting forest resources, this led to the blocking and reduction of fishing areas, to the silting up of the channel between Lake Acari and the river Trombetas, used for navigation, and compromising the quality (and potability) of the

2 - http://cpisp.org.br/quilombolas-em-oriximina/luta-pela-terra/exploracao-madeireira. 
waters of the Araticum and Saracá streams (NEPOMUCENO, 2017; AFFONSO, 2018).

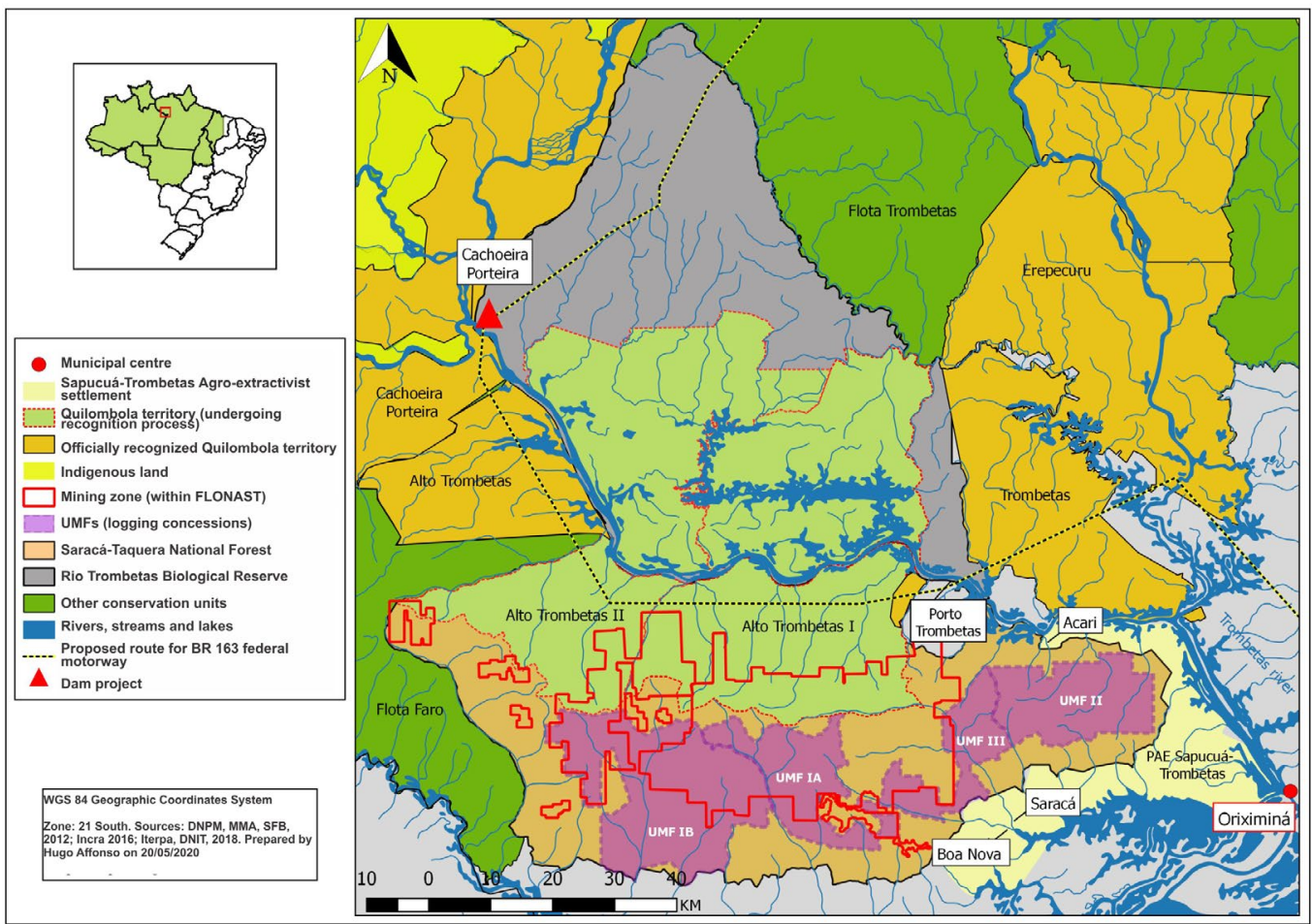

Figure 3. Map of the Trombetas basin with the location of protected areas, industrial and infrastructure projects and threats mentioned in the text

Source: Elaborated by the authors, 2021.

It is also worth noting that the lack of long-term multidisciplinary studies on extraction processes in environments of high complexity, connectivity and resilience (TRUMBOLACK et al., 2004) makes it difficult to assess the synergistic ecological effects of logging. Highly sensitive forest species may not withstand frequent disturbances (BARLOW et al., 2016); the exploitation of centuries-old forests in cycles of 30 years will inevitably lead to the rejuvenation and simplification of these ecosystems, causing the weakening of their ecosystem services, such as the carbon absorption capacity and support for high biological diversity. It was confirmed by Piponiot et al. (2019), who observed that, in 15 locations in different geographies in the Amazon, the extraction of $20 \mathrm{~m}^{3} /$ ha does not allow forest recovery at the end of the 30-year harvest cycle, concluding that selective extraction cannot provide enough wood to meet the current demand and the long-term market, even with cycles of 30 years of operation and low intensity management techniques.

The communities that live in and around Flonast managed, however, through articulations with allied researchers and the MPF, to cancel the FSC seal forest certifica- 
tion of the company that impacts their territories, Ebata (NEPOMUCENO, 2017). Also relevant are the articulations that quilombolas have been carrying out with ICMBio, which eventually proved to be a partner. The biological reserve is a strict-protection conservation unit, and the riberinhos, in their steadfast demand for land rights, arranged for them to be granted the right to Brazil nut extraction in their territories overlapped by UC. These old and continuous practices of mobilization, in addition to persistence in the territories, can be read as forms of daily resistance (SCOTT, 2002).

\section{Closing thoughts}

The comparative exercise carried out here shows that the Trombetas and Tapajós basins have long interconnected historical processes on a millenary scale, with connections recorded since pre-Columbian times. However, especially from the 20th century onwards, the allocation of public lands in the Trombetas basin and the non-allocation of large portions of public lands in the Tapajós basin lead the State and capital to articulate themselves through different plunder strategies (HARVEY, 2004) in those regions. The installation of mining, hydroelectric and logging projects and the exploration of traditionally occupied territories are not linear processes, as pointed out by Harvey (2004); the territorial expansion of capital involves the articulation of different fronts that can combine land grabbing, deforestation, agriculture, mining and related infrastructure (dams and waterways), with the assistance of the State, both in the field of discourse and in the alteration or elaboration of laws that benefit big capital to the detriment of indigenous peoples, traditional communities and peasants.

We aimed here to summarize the actions and networks of historical relationships of the social groups that inhabit these territories. Das and Poole (2008) argue that the theoretical reflection of the social sciences about the State should move towards understanding how the political practices of regulation and disciplining that constitute the power of the State are also challenged by the groups that inhabit the margins. This is well exemplified by the fact that today, even in the face of threats and violence, these social groups that live in the Tapajós and Trombetas basins - and which are often led by women - continue to resist expropriation or territorial dispossession, through multiple and varied strategies. Articulation with a constellation of allies and partners; the importance given to decision-making and communicative autonomy by the Munduruku; the alliance between the Munduruku and the Montanha and Mangabal community with the borders of Montanha and Mangabal; the elaboration of consultation protocols and direct actions that paralyse capitalist operations that may include partnerships with workers - are all examples of forms and strategies of resistance developed in the Tapajós basin. In the Trombetas basin, through conversations with allies, the riberinho communities achieved the cancellation of the FSC certification; quilombolas recovered the use of their territory, from where they had been expelled and resumed the collection of Brazil-nuts and the management of turtles - thus contributing decisively to the conservation of the environment. These varied strategies and actions refer to forms of organization based on the commons, as well as to permanent mobilization and attention, based on the history lived by these 
collectivities, marked in the landscape and transmitted orally through the generations.

In view of the current scenario of attacks on rights and dismantling of the apparatus for their guarantee, we must renew efforts to support the multiple forms of resistance of these forest peoples to carry out their struggles for life, nature and territory.

\section{Acknowledgements}

We are grateful to the beiradeiros of Montanha and Mangabal and to the Munduruku people on the Tapajós River; the riberinhos, quilombolas and indigenous people of the Trombetas River; to friends Maurício Torres, Natália Guerrero, Cândido Cunha, Rosamaria Loures and Rodrigo Oliveira for the information and indispensable help with the review. We are grateful to James Fraser, a member of the Historical and Political Ecology Study Network in the Trombetas, Tapajós and Xingu Basins for the English version of the text. We thank the anonymous referees for their valuable comments and the publishers and editors for their critical reviews. Research that produced a part of the data presented here was financed by the following funding agencies: CAPES Foundation (Full Doctorate Scholarship Abroad - Process BEX 1034 / 12-0); Institute of Archaeology Awards; UCL Graduate School Research Projects Fund; Amazon Protected Areas Program; National Postdoctoral Program of the Coordination for the Improvement of Higher Education Personnel and the National Council for Scientific and Technological Development - CNPq (Process number 426960 / 2016-5); Chico Mendes Institute for Conservation and Biodiversity.

\section{References}

ACEVEDO MARIN, R.; CASTRO, E. Negros do Trombetas: guardiães de matas e rios. 2. ed. Belém: CEPUJ, 1998.

AFFONSO, H. G. A disputa das unidades de conservação como territórios tradicionalmente ocupados e espaço destinado a concessões minerais e madeireiras: estudo de caso a partir dos conflitos na Floresta Nacional de Saracá-Taquera, Oriximiná - Pará. Dissertação (Mestrado em Ciências Ambientais). Universidade Federal do Oeste do Pará, Santarém, 2018.

ALARCON, D. F; MILLIKAN, B.; TORRES, M. (org.). Ocekadi: Hidrelétricas, conflitos socioambientais e resistência na Bacia do Tapajós. 1. ed. Brasília; Santarém: International Rivers; PAA/Universidade Federal do Oeste do Pará, 2016.

ALARCON, D. F.; GUERRERO, N. R.; TORRES, M. "Saída pelo norte": a articulação de projetos de infraestrutura e rotas logísticas na bacia do Tapajós. In: ALARCON, D.F.; MILLIKAN, B; TORRES, M. (org.). Ocekadi: Hidrelétricas, conflitos socioambientais e resistência na bacia do Tapajós. 1. ed. Brasília; Santarém: International Rivers; PAA/Universidade Federal do Oeste do Pará, p. 43-78, 2016. 
ALARCON, D. F; GUERRERO, N. R.; FURUIE, V. A. Imprensa e barragens na bacia do Tapajós: apego ao discurso oficial e ocultamento das críticas. In: ALARCON, D.F; MILLIKAN, B; TORRES, M. (org.). Ocekadi: Hidrelétricas, conflitos socioambientais e resistência na bacia do Tapajós. 1. ed. Brasília; Santarém: International Rivers; PAA/Universidade Federal do Oeste do Pará, p. 211-245, 2016.

ALIMONDA, H. 2011. La colonialidad de la naturaleza. Una aproximación a la Ecología Política Latinoamericana. In: ALIMONDA, H (Ed.). La naturaleza colonizada:ecología política y minería en América Latina. Buenos Aires: CLACSO, p. 21-58, 2011.

ALIMONDA, H. En clave de sur: la Ecología Política Latinoamericana y el pensamiento crítico. In: ALIMONDA, H.; TORO PÉREZ; MARTÍN, F. (Coord.). Ecología política latinoamericana:pensamiento crítico, diferencia latinoamericana y rearticulación epistémica. 1. ed, Buenos Aires: CLACSO; México: Universidad Autónoma Metropolitana; Ciudad Autónoma de Buenos Aires: Ciccus, p. 33-51, 2017.

ALMEIDA, M. W. B. Rubber tappers of the upper Juruá river, Brazil: the making of a forest peasant economy. Tese de Doutorado. Universidade de Cambridge, Cambridge, 1993.

ANGELO, M. Projeto da Ferrogrão, alvo de disputa internacional, segue sem consulta prévia aos povos indígenas. Inesc, 2019. Disponível em: < https://www.inesc.org.br/projeto-da-ferrograo-alvo-de-disputa-internacional-segue-sem-consulta-previa-aos-povos-indigenas/>. Acesso em: 13 set. 2019.

ARAÚJO, R.; ASSUNÇÃO, J.; BRAGANÇA, A. Os impactos ambientais da Ferrogrão: uma avaliação ex-ante dos riscos de desmatamento. Rio de Janeiro: ClimatePolicyInitiative, 2020.

ARBEX JR., J. 2005. "Terra sem povo”, crime sem castigo: pouco ou nada sabemos de concreto sobre a Amazônia In: TORRES, M. (org.). Amazônia revelada: os descaminhos ao longo da BR163. 1. ed. Brasília: CNPq, p. 21-67, 2005.

BALÉE, W. The culture of Amazonian forests. In: POSEY, D.; BALÉE, W. (org). Resource Management in Amazonia: Indigenous and Folk Strategies. New York: New York Botanical Gardens, v. 7, p. 1-21, 1989.

BALÉE, W. Historical Ecology: premises and postulates. In: BALEÉ, W. (org.). Advances in Historical Ecology. New York: Columbia University Press, p. 13-27, 1998.

BALÉE, W.; HONORATO DE OLIVEIRA, V.; SANTOS, R; AMARAL, M.; ROCHA, B.; GUERRERO, N.; SCHWARTZMAN, S.; TORRES, M.; PEZZUTI, J. Ancient Transformation, Current Conservation: Traditional Forest Management on the Iriri River, Brazilian Amazonia. Human Ecology, v. 48, p. 1-15, 2020.

BARLOW, J.; LENNOX, G. D.; FERREIRA, J.; BERENGUER, E.; LEES, A. C. NALLY, R. C. et al. Anthropogenic disturbance in tropical forests can double biodiversity loss from deforestation. Nature, v. 535, p. 144-147, 2016.

BRASIL. Lei Ordinária no 9.985, de 18 de julho de 2000. Institui o Sistema Nacional de Unida- 
des de Conservação da Natureza e dá outras providências. Diário Oficial da União, Brasília, DF, 19 jul. 2000.

BRASIL. Ministério do Meio Ambiente. Instrução Normativa №. 5, de 11 de dezembro de 2006. Dispõe sobre procedimentos técnicos para elaboração, apresentação, execução e avaliação técnica de Planos de Manejo Florestal Sustentável- PMFS nas florestas primitivas e suas formas de sucessão na Amazônia Legal, e dá outras providências. Diário Oficial da União, Brasília, DF, n⿳o 238, Seção 1, p. 155, 13 dez. 2006.

BRASIL. Justiça Federal. Subseção Judiciária de Itaituba. Ação Civil Pública no. 100207372.2020.4.01.3908. Itaituba: JF, 2020.

BUENO, M. F. O imaginário brasileiro sobre a Amazônia. Dissertação (Mestrado em Geografia Humana) - Faculdade de Filosofia, Letras e Ciências Humanas, Universidade de São Paulo, São Paulo, 2002.

CARNEY, J. A.; VOEKS, R. A. Landscape legacies of the African diaspora in Brazil. Progress in Human Geography, v. 27, n. 2, p. 139-152, 2003.

COELHO, M. C. N.; CUNHA, L. H.; WANDERLEY, L. J. de M. Conflitos em áreas de mineração na Amazônia:os casos dos quilombolas e dos moradores e beiras de lagos, dos canais fluviais e de estradas em Oriximiná. In: ZHOURI, A; LASCHEFSKI, K. Desenvolvimento e conflitos ambientais. 1. reimp. Belo Horizonte: Editora UFMG, p. 276-301, 2017.

Comissão Pró-Índio de São Paulo. Terras Quilombolas em Oriximiná. 2020. Disponível em:

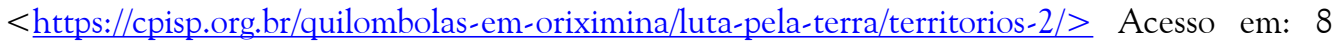
jan. 2021.

DAS,V; POOLE, D. El estado y sus márgenes. Etnografias comparadas. Cuadernos de Antropología Social, n. 27, p, 19-52, 2008.

ESCOBAR, A. O lugar da natureza e a natureza do lugar: globalização ou pós-desenvolvimento? In: Edgardo Lander, (org.). A colonialidade do saber: eurocentrismo e ciências sociais. Perspectivas latino-americanas. Buenos Aires: ColecciónSur, CLACSO, p. 133-168, 2005.

FEARNSIDE, P. M. Brazil's São Luiz do Tapajós Dam: The Art of Cosmetic Environmental Impact Assessments. Water Alternatives, 8/3, p. 373-396, 2015.

FOUCAULT, M. Segurança, território, população: curso dado no Collége de France (19771978). São Paulo: Martins Fontes, 2008.

FUNES, E. Comunidades mocambeiras do Trombetas. In: GRUPIONI, D. F; DE ANDRADE, L. M. M. (org). Entre Águas Bravas e Mansas, índios \& quilombolas em Oriximiná. São Paulo: Comissão Pró-Índio de São Paulo; Iepé, 2015.

GUAPINDAIA, V. Além da margem do rio: a ocupação Konduri e Poço na região de Porto Trombetas. 2008. Tese de Doutorado. Universidade de São Paulo, São Paulo, 2008. 
GUDYNAS, E. Ecologías políticas. Ideas preliminares sobre concepciones, tendencias, renovaciones y opcioneslatinoamericanas. Documentos de trabajo CLACSO n.ำ72, p 1-17, 2014. (Documento de trabajo CLACSO, 72).

GUERRERO, N. R.; TORRES, M.; NEPOMUCENO, I. Impactos da Lei de Gestão de Florestas Públicas a comunidades tradicionais na Flona do Crepori. Ambiente e Sociedade, São Paulo, v. 23, p. 1-20, 2020.

HARRIS, M. The Making of Regional Systems: The Tapajós/Madeira and Trombetas/Nhamundá Regions in the Lower Brazilian Amazon, Seventeenth and Eighteenth Centuries. Ethnohistory, v. 65, n. 4, p. 621-645, 2018.

HARVEY D. O novo Imperialismo. São Paulo: Loyola, 2004.

HORBE, A. M. C.; OLIVEIRA, L. G. S. Química de igarapés de água preta do nordeste do Amazonas - Brasil. Acta Amazonica, v. 38, n. 4, p. 753-760, 2008.

HOORN, C.; WESSELINGHT, F. Amazonia: Landscape and Species Evolution: A Look into the Past. Oxford: Wilew-Blackwell, 2010.

IBAMA - Instituto Brasileiro de Meio Ambiente e Recursos Naturais. Plano de Manejo da Reserva Biológica do Rio Trombetas. Ministério de Meio Ambiente, Brasília, 2004.

IORIS, E. M. Na trilha do manejo científico da floresta tropical: indústria madeireira e florestas nacionais. Boletim Museu Paraense Emílio Goeldi - Ciências Humanas, Belém, v. 3, n. 3, p. 289-309, 2008.

INSTITUTO SOCIOAMBIENTAL. Monitoramento de áreas protegidas. Disponível em: https://www.socioambiental.org/pt-br/o-isa/programas/monitoramento-de-areas-protegidas. Acesso: 20 de outubro de 2020.

NOGUEIRA, M. M.; VIEIRA, V.; SOUZA, A.; LENTINI, M. W. Manejo de florestas naturais da Amazônia: corte, traçamento e segurança. Belém, PA: Instituto Floresta Tropical, 2011.

KOCH, A.; BRIERLEY, C.; MASLIN, M.M.; LEWIS, S.L. Earth system impacts of the European arrival and Great Dying in the Americas after 1492. QuatSciRev 207, p. 13-36, 2019.

KRENAK. A. Ideias para adiar o fim do mundo. São Paulo: Companhia das Letras, 2019.

LEFF. E. La Ecología Política En América Latina: un campo en Construcción. Sociedade e Estado, v. 18, n. 1/2, p. 17-40, 2003.

LEVIS, C.; COSTA, F. R. C. ; BONGERS, F; PEÑA-ClAROS, M.; CLEMENT, C. R.; JUNQUEIRA, A. B., et al. Persistent effects of pre-Columbian plant domestication on Amazonian forest composition. Science, v. 355, p. 925-931, 2017.

LOURES, R. S. P. Governo Karodaybi: o movimento IpereğAyũ e a resistência Munduruku. Dissertação (Mestrado em Ciências Ambientais). Universidade Federal do Oeste do Pará, San- 
tarém, 2017.

LOURES, R. S. P.; BRANFORD, S. Indígenas Munduruku resgatam urnas sagradas desenterradas durante construção de hidrelétrica. Tradução Thaís Borges. Mongabay. 2020. Disponível em: < https://brasil.mongabay.com/2020/01/indigenas-munduruku-resgatam-urnas-sagradas-desenterradas-durante-construcao-de-hidreletrica/>. Acesso em: 7 jan. 2021.

MARTÍNEZ ALIER, J. Ecología política del extractivismo y justicia socio-ambiental. Interdisciplina, v.3, n 7, p 57-73, 2015.

MARTINS, J. S. O tempo da fronteira. Retorno à controvérsia sobre o tempo histórico da frente de expansão e da frente pioneira. Tempo Social, v. 8, n 1, p. 25-70, 1996.

MONTEIRO, J. Tupis, Tapuias e Historiadores: estudos de História Indígena e do Indigenismo. 2001. Tese (Doutorado em Antropologia). Universidade de Campinas, Campinas, 2001.

MORAIS, R. Águas Brancas, Pretas e Verdes. In: AB'SABER, A. (ed.). Leituras Indispensáveis. São Paulo: Ateliê Editorial, p.57-63, 2008.

NEPOMUCENO, I. T. R.; AFFONSO, H. G.; FRASER, J. A.; TORRES, M. Counter-conducts and the green grab: Forest peoples' resistance to industrial resource extraction in the Saracá-Taquera National Forest, Brazilian Amazonia. Global Environmental Change, v. 56, p. 124 $133,2019$.

NEPOMUCENO, I. T. R. Conflitos territoriais entre comunidades tradicionais e concessões florestais: um estudo de caso a partir da Floresta Nacional de Saracá-Taquera em Oriximiná, Pará. Dissertação (Mestrado em Ciências Ambientais). Universidade Federal do Oeste do Pará, Santarém, 2017.

NEVES, E. G., GUAPINDAIA, V. L. C., LIMA, H. P., COSTA, B. L. S.; GOMES, J. A tradição Pocó-Açutuba e os primeiros sinais visíveis de modificações de paisagens na calha do Amazonas. In: ROSTAIN, S. (ed.). Amazonía: memorias de las Conferencias Magistrales del 3er Encuentro Internacional de Arqueología Amazônica.Quito: Ministerio Coordinador de Conocimiento y Talento Humano e IKIAM, Secretaría Nacional de Educación Superior, Ciencia, Tecnología e Innovación, Tercer Encuentro Internacional de Arqueología Amazónica, p. 137-158, 2014.

NEVES, E. G. Arqueologia Amazônica. Rio de Janeiro: Jorge Zahar, 2006.

PIPONIOT, C.; RÖDIG, E.; PUTZ, F. E.; RUTISHAUSER, E.; SIST, P.; ASCARRUNZ, N. et al.Can timber provision from Amazonian production forests be sustainable? Environmental ResearchLetters, v. 14, p. 064014, 2019.

OLIVEIRA, A. U. BR-163 Cuiabá-Santarém: Geopolítica, grilagem, violência e mundialização. In: TORRES, M. (org.) Amazônia revelada: os descaminhos ao longo da BR-163. 1. ed. Brasília: CNPq, p. 67-184, 2005.

OLIVEIRA, R. M. "Respeitem a forma de a gente ser": Protocolo de Consulta Munduruku e pluralismo jurídico. Direito e Práxis, Rio de Janeiro, 2020. Disponível em: https://www.e-publi- 
cacoes.uerj.br/index.php/revistaceaju/article/view/50663. Acesso em: 8 jan. 2021.

POVO MUNDURUKU. Carta dos Munduruku ao governo explicitaconhecimentos milenares e reafirma demandas. Conselho Indigenista Missionário (CIMI). Carta publicada em 10 jun. 2013. Disponível em:<https://cimi.org.br/2013/06/34922/>. Acesso em: 25 maio 2020.

ROCHA, B. C. Ipi Ocemumuge: A Regional Archaeology of the Upper Tapajós River. 2017. Tese de Doutorado. Institute of Archaeology, University College, London, 2017.

ROCHA, B. C. 2020. 'Rescuing' the ground from under their feet? Contract archaeology and human rights violations in the Brazilian Amazon. In: APAYDIN, V. (org.). Critical Perspectives on Cultural Memory and Heritage: Construction, Transformation and Destruction. Londres: UCL Press, p. 169-188, 2020.

SCOLES, R. Caracterização ambiental da bacia do Tapajós. In: ALARCON, D. F., MILLIKAN, B., TORRES, M. (Org). Ocekadi: Hidrelétricas, Conflitos Socioambientais e Resistência na bacia do Tapajós. 1. ed. Brasília: International Rivers; Santarém: PAA/UFOPA, p. 29-42, 2016.

SCOLES, R.; GRIBEL, R. Human influence on the Regeneration of Brazil nut tree (Bertholletiaexcelsa, Lecythidaceae) at the Capanã Grande Lake, Manicoré, Amazonas, Brazil. Human Ecology, v. 43, n. 6, p. 843-854, 2011.

SCOLES, R.; GRIBEL, R. The regeneration of Brazil nut trees in relation to nut harvest intensity in the Trombetas River valley of Northern Amazonia, Brazil. Forest Ecology Management, v. 265, n. 1, p. 71-81, 2012.

SCOLES, R.; GRIBEL, R. Growth and survival over ten years of Brazil nut trees planted in three anthropogenic habitats in northern Amazonia. Acta Amazonica, v. 5, n. 1, p. 20-29, 2021.

SHOCK, M. P.; MORAES, C. P. A floresta é o domus: a importância das evidências arqueobotânicas e arqueológicas das ocupações humanas amazônicas na transição Pleistoceno/Holoceno. Boletim do Museu Paraense Emilio Goeldi - Ciências Humanas, v. 14, p. 263-89, 2019.

SILVA, J. M. C.; RYLANDS, A. B.; FONSECA, G. A. B. The Fate of the Amazonian Areas of Endemism. Conservation Biology, v. 19, n. 3, p. 689-694, 2005.

SIMÕES, M. F. Nota Sobre Duas Pontas de Projétil da Bacia Tapajós (Pará). Boletim do Museu Paraense Emílio Goeldi Nova Série, v. 62, 1976.

SCOTT, J. Formas cotidianas da resistência camponesa. Raízes, v. 21, p. 10-31, 2002.

SVAMPA, M. Las fronteras del neoextractivismo en América Latina: conflictos socioambientales, giro ecoterritorial y nuevasdependencias. Guadalajara: CALAS, 2019.

TORRES, M. (org.) Amazônia revelada: os descaminhos ao longo da BR-163. 1. ed. Brasília: CNPq, 2005.

TORRES, M. A beiradeira e o grilador: ocupação e conflito no Oes- 
te do Pará. Dissertação (Mestrado em Geografia) - Faculdade de Filosofia, Letras e Ciências Humanas, Universidade de São Paulo, São Paulo, 2008. TORRES, M. A despensa viva: um banco de germoplasma nos roçados da floresta. Geografia em Questão, v. 4, n. 2, p. 113-138, 2011.

TORRES, M. Terra privada, vida devoluta: ordenamento fundiário e destinação de terras públicas no oeste do Pará. Tese (Doutorado em Geografia) - Faculdade de Filosofia, Letras e Ciências Humanas, Universidade de São Paulo, São Paulo, 2012.

TORRES, M. De pariwat ('étrangers/ennemis') à wuyḡuybugum ('ceuxquipensentcommenous'): scissions et alliances de groupes sociaux distincts atteints par des menaces communes. In: Identités et territoires: une approchepatrimoniale (Symposium). Paris: École des Hautes Études en Sciences Sociales, 2015.

TORRES, M. Um rio de muita gente: a luta comum de vidas plurais no vale do Alto Tapajós. In: ALARCON, D. F; MILLIKAN, B; TORRES, M. (Org.). Ocekadi: hidrelétricas, conflitos socioambientais e resistência na Bacia do Tapajós. 1. ed. Brasília; Santarém: International Rivers; PAA/Universidade Federal do Oeste do Pará, p. 1-28, 2016.

TORRES, M; DOBLAS, J.; ALARCON, D. F. "Dono é quem desmata”: conexões entre grilagem e desmatamento no sudoeste paraense. 1. ed. São Paulo: Urutu Branco; Instituto Agronômico da Amazônia, 2017.

TORRES, M.; BRANFORD, S. Índios fecham Transamazônica e conquistam vitória com apoio de caminhoneiros. Mongabay, 2017. Disponível em: < https://brasil.mongabay.com/2017/05/ indios-fecham-transamazonica-conquistam-vitoria-apoio-caminhoneiros/> Acesso em: 6 jan. 2021.

TORRES, M. Grilagem para principiantes: guia de procedimentos básicos para o saqueio de terras públicas. In: MARQUES, M. I. M. et al. (org.). Perspectivas de Natureza: geografia, formas de natureza e política. 1ed.Brasília; São Paulo: CNPq; Anna Blume, p. 285-314, 2018.

TORRES, M.; CUNHA, C.; GUERRERO, N. Ilegalidade em moto contínuo: o aporte legal para destinação de terras públicas e a grilagem na Amazônia. In: OLIVEIRA, Ariovaldo U. (org.). A grilagem de terras na formação territorial brasileira. São Paulo: FFLCH/USP, 2020.

TROMBULAK, S. C.; OMLAND, K. S.; ROBINSON, J. A.; LUSK, J. J.; FLEISCHNER, T. L.; BROWN, G.; DOMROESE, M. Princípios da Biologia da Conservação: Diretrizes para o Ensino da Conservação recomendadas pelo Comitê de Educação da Sociedade para a Biologia da Conservação. Conservation Biology, v. 18, p. 1180-90, 2004.

WANDERLEY, L. J. D. M. Tem "cerca” para negro na Amazônia! A Luta dos Quilombolas do Trombetas - PA por Titulação e uso da terra. III Simpósio Nacional de Geografia Agrária - II Simpósio Internacional de Geografia Agrária, Presidente Prudente-SP: Universidade Federal do Rio Janeiro, 2005.

WHITEHEAD, N. L. Ethnic Transformation and Historical Discontinuity in Native Amazonia and Guayana, 1500-1900. L'Homme, 33/126-128. La remontée de l'Amazone, p. 285-305, 1993. 


\section{Bruna Cigaran da Rocha}

$\checkmark$ bruna.rocha@ufopa.edu.br

ORCiD: https://orcid.org/0000-0003-4250-0946
Submitted on: 03/07/2019

Accepted on: 14/03/2021

2021;24e:00951

\title{
Diego Amoedo Martínez
}

$\checkmark$ diego.amoedo.martinez@gmail.com

ORCiD: https://orcid.org/0000-0001-8268-0107

\section{Hugo Gravina Affonso}

$\varangle$ hugogravinaaffonso@gmail.com

ORCiD: https://orcid.org/0000-0003-4123-3831

\section{Susan Aragon}

$\checkmark$ saragongeo@yahoo.com

ORCiD: https://orcid.org/0000-0002-7364-6094

\section{Vinicius Honorato de Oliveira}

$\checkmark$ vinicius_honorato@yahoo.com

ORCiD: https://orcid.org/0000-0002-4176-5451

\author{
Ricard Scoles \\ $\varangle$ ricardscoles@yahoo.es \\ ORCiD: https://orcid.org/0000-0001-8483-6523
}

How to cite: ROCHA, B.C.; AMOEDO MARTÍNEZ, D.; AFFONSO, H.G.; ARAGON, S.; HONORATO DE OLIVEIRA, V.; SCOLES, R. Plunder and resistance in traditionally occupied territories of the Tapajós and Trombetas basins, Pará state, Brazilian Amazonia. Ambiente \& Sociedade. São Paulo, v. 24, p. 1-21, 2021. 


\title{
Espoliação e resistência em territórios tradicionalmente ocupados nas bacias dos rios Tapajós e Trombetas, Pará
}

\author{
Bruna Cigaran da Rocha \\ Diego Amoedo Martínez \\ Hugo Gravina Affonso \\ Susan Aragon \\ Vinicius Honorato de Oliveira \\ Ricardo Scoles
}

São Paulo. Vol. 24, 2021

Tema em Destaque:

Insurgências Deco-

loniais e Horizontes

Emancipatórios: Contribuições da Ecologia Política
Resumo: Na América Latina, é particularmente relevante uma abordagem crítica pós-desenvolvimentista, que vincula estreitamente a modernidade à colonialidade e cujos debates são permeados pelo conceito de natureza colonizada e por críticas severas ao neoextrativismo do século XXI. O artigo apresenta a diversidade social e o patrimônio biocultural dos povos da floresta que vivem nas bacias dos rios Tapajós e Trombetas e, a partir de uma análise de áreas e situações específicas, reflete sobre formas de espoliação perpetradas pelo capital, em conluio com diferentes esferas do Estado. Essa análise, por sua vez, permite tecer reflexões sobre as diferentes formas de resistência dos povos da floresta em defesa de seus territórios tradicionalmente ocupados e modos de vida.

Palavras-chave: Avaliação de Impacto Ambiental, Diversidade Biológica, Uso da terra.

Como citar: ROCHA, B.C.; AMOEDO MARTÍNEZ, D.; AFFONSO, H.G.; ARAGON, S.; HONORATO DE OLIVEIRA, V.; SCOLES, R. Espoliação e resistência em territórios tradicionalmente ocupados nas bacias dos rios Tapajós e Trombetas, Pará. Ambiente $\mathbb{\&}$ Sociedade. São Paulo, v. 24, p. 1-22, 2021. 


\title{
Expoliación y resistencia en territorios tradicionalmente ocupados en las cuencas de Tapajós y Trombetas (Amazonía brasileña)
}

\author{
Bruna Cigaran da Rocha \\ Diego Amoedo Martínez \\ Hugo Gravina Affonso \\ Susan Aragon \\ Vinicius Honorato de Oliveira \\ Ricardo Scoles
}

São Paulo. Vol. 24, 2021

Tema en Destaque:

Insurgencias decoloniales y Horizontes emancipatórios:
Resumen: En América Latina, es particularmente relevante el enfoque crítico pós-desarrollista, que relaciona estrechamente la modernidad a la colonialidad y cuyos debates son marcados por el concepto de naturaleza colonizada y por críticas rigurosas al neoextractivismo del siglo XXI. Este artículo revela la diversidad social y el patrimonio biocultural de los pueblos de la selva que viven en las cuencas de los ríos Tapajós y Trombetas, y, a partir de un análisis de áreas y situaciones específicas, reflexionamos sobre formas de expoliación perpetradas por el capital en connivencia con diferentes esferas del Estado. Este análisis, además, permite tejer reflexiones sobre diferentes formas de resistencia de estos pueblos en defensa de sus territorios tradicionalmente ocupados y modos de vida.

Palabras-clave: Tapajós, Trombetas, Ecología política, Expoliación, Resistencia

Como citar: ROCHA, B.C.; AMOEDO MARTÍNEZ, D.; AFFONSO, H.G.; ARAGON, S.; HONORATO DE OLIVEIRA, V.; SCOLES, R. Expoliación y resistencia en territorios tradicionalmente ocupados en las cuencas de Tapajós y Trombetas (Amazonía brasileña). Ambiente \& Sociedade. São Paulo, v. 24, p. 1-22, 2021.

DOI: http://dx.doi.org/10.1590/1809-4422asoc20200095r1vu2021L3AO 


\section{ERRATUM}

In the article Plunder and resistance in traditionally occupied territories of the Tapajós and Trombetas basins, Pará state, Brazilian Amazonia, with DOI number: http://dx.doi.org/10.1590/1809. 4422asoc20200095r1vu2021L3AO, published in the journal Revista Ambiente \& Sociedade, Vol 24, On page 01, 22 and 23

Which read:

DOI: http://dx.doi.org/10.1590/1809-4422asoc20190031r3vu2021L3AO

Read:

DOI: http://dx.doi.org/10.1590/1809-4422asoc20200095r1vu2021L3AO 